\title{
A Grounded Theory Analysis on the Life Experiences of Adults who Stutter
}

\author{
Soyoung Choi ${ }^{\mathrm{a}}$, Miseung Song ${ }^{\mathrm{b}}$, Moonja Shin ${ }^{\mathrm{c}}$ \\ ${ }^{a}$ Mokpo speech language hearing center, Mokpo, Korea \\ ${ }^{b}$ Department of Nursing, Sehan University, Yeongam, Korea \\ 'Division of Speech-Language Pathology, Chosun University, Gwangju, Korea
}

\author{
Correspondence: Miseung Song, $\mathrm{PhD}$ \\ Department of Nursing Sehan University, 1113 \\ Green-ro, Samho-eup, Yeongam-gun, Jeonnam \\ 58447 , Korea \\ Tel: + 82-6-1469-1477 \\ Fax: +82-6-1469-1477 \\ E-mail: sms5956@hanmail.net
}

Received: October 5, 2020

Revised: November 13, 2020

Accepted: November 18, 2020

This article is based on a part of the first author's doctoral thesis from Chosun University.

\begin{abstract}
Objectives: The purpose of this study was to offer a theoretical framework for speech language pathologists in the clinical field and community to use or identifying the life experiences of adults who stutter. Methods: This study was based on the Grounded Theory method provided by Strauss \& Corbin (1998), which study included 10 adults who stutter. Results: The core phenomenon in the life experiences of adults who stutter was identified as "Unconscious occupation of stuttering: yoke". The causal conditions of the core phenomenon were found to be "Awareness of stuttering" and "Object of ridicule". This was reinforced by the contextual conditions of "Tension", "Fear" and "Withdrawal". "Preconceived expectations", "Passion for accomplishment" and "Open mind" were found to be the intervening conditions regarding this core phenomenon. Among strategies reported for the core phenomenon were "Positive advances", "Struggle alone", "Self-repression". Those strategies made them "Adaptation", "Self-torment", "Helpless" and "Giving-up". The life experiences of adults who stutter were classified into four types, and the process was analyzed as "Emergence stages", "Internalization stages" and "Transition stages". Conclusion: It was discussed and ultimately decided that the development and application of practical intervention and counseling programs were required based on the type and process of life experiences of people who stutter.
\end{abstract}

Keywords: Adults who stutter, Life experiences, Grounded theory
말더듬은 의사소통장애 중 매우 복잡한 현상이며(Manning, 2010) 관찰이 가능한 외현적 특성과 눈으로 확인하기 어려운 인지 및 감정적인 내재적 특성으로 크게 나누어 설명한다. 특히 말더듬 의 내재적 특성은 감정적 특성, 인지적 특성, 의사소통 태도의 특성 그리고 통제력 상실이라고 나누어 규정할 수 있다(Yairi \& Seery, 2011). 말더듬성인들은 이러한 내재적 특성을 오랜 시간 동안 반복 적으로 경험하게 되며 의사소통과 사회 참여에 제약을 받는 삶의 양식을 선택하게 되기도 하며(Anderson \& Felsenfeld, 2003; Crichton-Smith, 2002; Plexico, Manning, \& Levitt, 2009a, 2009b) 말을 더듬지 않는 성인들에 비해 사교적인 상황이나 공적인 상황을 의도 적으로 피하기도 한다(Van Riper, 1982). 따라서 말더듬성인들이 불안정한 의사소통으로 인해 정상적인 사회생활을 포기하게 되는 결과로 이어질 수 있으며, 직장에서의 낮은 과업 수행력을 보이기도
한다(Michelle \& Eleanor, 2004). 이렇듯 말더듬은 삶에 깊숙이 영 향을 끼치며 그 영향으로 인하여 삶 속에서의 문제로 자리잡게 된 다. 이는 말더듬이 단순히 신체적인 말 산출의 문제 이상의 것을 포 함한다는 인식으로 보는 반응이므로, 말더듬 연구에 질적연구 방 법론을 적용하는 것이 적합할 수 있다(Smith, 1999; Yaruss \& Quesal, 2004).

질적연구는 연구자의 시각을 통해 특정한 사회 문화적 행동이나 현상이 어떻게 작용하는지 그리고 무엇이 진행되고 있는지를 파악 하는 것이 목적이다. 인간이 사회적 행동을 취하고 그것이 어떻게 작동하는지를 파악함으로써, 양적연구와는 다른 연구방법을 적용 한다. 양적연구는 주로 통계 분석을 사용하여 가설을 입증하기 위 해 고안된 반면, 질적연구는 연구하고자 하는 사회 현상의 절차적 문제를 이해하고자 한다. 어떤 현상이 일어난다는 사실보다는 현 
상이 어떻게 일어나는가에 관심의 초점이 있다. 또한 질적연구는 잘 알려져 있지 않은 새로운 이해를 얻기 위해 실재적 분야를 탐색 하는데 사용될 수 있다(Stern, 1980). 게다가 느낌, 사고 과정, 감정 과 같이 기존의 연구방법을 통해서는 추출하거나 알아내기 어려운 복잡한 현상에 대한 세부 사항을 얻기 위해 사용한다(Strauss \& Corbin, 1998). 이에 Stewart와 Richardson (2004)은 치료의 효과 및 결과를 알아보는 양적연구에서는 결과에 대한 지식은 있으나, 치료 과정에서 대상자의 개인적 경험이나 과정에 대한 이해가 부족 할 수 있다고 지적한바 있다. Tetnowski와 Damico (2001)는 말더 듬에 대한 연구에서 질적연구 방법론의 적용에 대한 장점과 유용 성을 제시하였는데 연구자들은 말더듬 관련 현상과 대상자들이 사회적 맥락에서 말더듬 때문에 받는 부정적인 영향을 줄이기 위 해 어떤 시도를 하는지에 대해 자세히 배울 수 있다고 하였다.

지금까지 국내외에서 말더듬성인들의 삶에 대한 다양한 질적연 구가 이루어졌다. 말더듬성인의 삶에 대한 국외 질적연구로는 말더 듬과 직장생활(Bricker-Katz, Lincoln, \& Cumming, 2013), 성공적 인 말더듬 관리(Plexico, Manning, \& DiLollo, 2005), 말더듬에 대 한 대처 전략(Plexico et al., 2009a, 2009b), 말더듬 관련 삶의 경험, 치료 경험, 말더듬 회복 특성(Corcoran \& Stewart, 1998; CrichtonSmith, 2002; Daniels, Hagstrom, \& Gabel, 2006; Stewart \& Richardson, 2004), 그리고 말더듬 지원 그룹(National Stuttering Association) 참여자를 대상으로 말더듬이 삶에 미치는 영향, 치료 그리 고 정보에 대한 견해를 알아보는 연구들이 있다(Hayhow, Cray, \& Enderby, 2002; Yaruss, Quesal, \& Murphy, 2002). 국내에서 이루어 진 말더듬성인에 관한 질적연구로는 20대 말더듬성인의 말더듬 경 험(Hwang, 2012), 말더듬성인의 말더듬 극복에 대한 경험(Hwang, Hwang, \& Lee, 2018) 그리고 말더듬성인의 자기 공개(Kim, 2015) 가 있다. 국내외 말더듬성인에 대한 질적연구들은 주로 현상학적 방법론의 분석을 통해 말더듬에 대하여 어떻게 반응하는지, 성공 적인 말더듬 치료에 대하여 어떻게 이해하고 있는지, 치료 후 자조 그룹 참여 경험은 어떠한지 등의 현상에 대한 측면에서 이루어졌 다. 또한 이러한 연구들은 성인들이 말더듬으로 인하여 겪는 다양 한 경험, 극복 그리고 대처 과정의 중심 주제를 밝히거나 의미에 대 하여주목하였다.

Manning (2010)은 Corcoran과 Stewart (1998)의 말더듬성인의 경험을 소개하면서 언어재활사가 해야 할 첫 번째 일은 말더듬으로 인한 삶의 경험의 본질과 말더듬성인의 인생에 얼마나 많은 영향을 미치는가를 가슴으로 이해하는 것이라고 하였다. 말더듬성인에게 말더듬으로 인한 삶의 경험에 대한 과정과 의미도 중요하지만 그 경 험의 과정을 통해 말더듬의 문제를 어떻게 해결해 나가는지를 밝히
는 삶의 경험에 대한 실체적 이론이 제시되어야 한다. 따라서 말더 듬성인의 삶의 경험에 대한 전반적인 과정을 면밀하게 살펴보고 그 들의 삶의 유형을 밝히고 핵심적인 과정을 확인할 필요가 있다.

근거이론 방법론은 질적연구 방법론 중에서도 문제 중심적 접근 방법으로 사례를 재구성하는 과정에서 개인의 행동변화를 설명해 주고 상호작용을 통한 메커니즘을 분석하는데 유용할수 있다(Kim, Lee, \& Lee, 2012). 특히 근거이론 방법론은 연구 참여자들의 주된 문제를 스스로 어떻게 해결해 나가는지를 밝혀서 이론화하는 작업 으로(Choe, 2005), 말더듬의 발현기인 발달기에서부터 말더듬이 만 성화된 성인의 일생을 걸쳐 말더듬으로 인한 삶의 경험과 적응 과 정을 보다 면밀하게 파악하는데 적합할 것으로 사료된다.

따라서 본 연구는 근거이론 방법론을 이용하여 말더듬성인의 삶 의 경험에 대한 전반적인 과정의 유형을 밝히고, 그 경험들이 어떻 게 상호 관련 및 말더듬의 문제를 어떻게 해결해 나가는지를 규명하 고자 하였다. 이에 본 연구는 말더듬성인의 삶의 경험을 실재적인 관점에서 수집한 경험적 자료를 분석하여 말더듬성인의 삶의 경험 에 대한 유형과 과정 분석 및 실체이론을 개발함으로써 그들의 삶 의 질을 증진할 수 있는 전략 개발의 기초자료를 제공하고자 한다.

\section{연구방법}

\section{연구참여자}

연구의 참여자는 광주 · 전남 그리고 서울지역에 소재하는 말더 듬치료 전문기관에 말더듬으로 평가가 의뢰되었거나 언어치료를 받은 경험이 있는 말더듬성인 10 명이다. 연령은 20 대에서 60 대였으 며 8 명의 남성과 2 명의 여성이었다. 선정기준은 (1) 스스로 말을 더 듬는다고 보고하며, (2) 파라다이스-유창성검사 II (Pradise-Fluency Assessment II; Sim, Shin, \& Lee, 2010) 필수과제와 의사소통태 도 검사 결과를 토대로 말더듬으로 진단되고, (3) 수용·표현어휘력 검사(Receptive \& Expressive Vocabulary Test; Kim, Hong, Kim, Jang, \& Lee, 2009) 실시 결과 언어의 문제가 없으며, (4) 말더듬 이외 에 신체, 정서 및 기타 발달상의 문제와 신경학적인 장애가 없는 사 람들이었다. 참여자는 면담의 순서대로 기술하였고 참여자 특성은 Table 1과 같다.

\section{자료수집}

본 연구는 2016년 2월 중순부터 9월 중순까지 진행되었다. 제1연 구자가 10 명의 말더듬성인과 심층면담을 통하여 자료를 수집하였 으며, 심층면담에 소요된 시간은 50 분- 2 시간, 면담횟수는 1 회부터 2 회까지 진행되었다. 면담장소는 언어치료실이나 분리된 공간이 있 
Table 1. Participants' characteristics

\begin{tabular}{|c|c|c|c|c|c|c|c|}
\hline ID & Age & Gender & Highest level of education completed & Occupation & Area & Stuttering severity (\%ile) & Duration of therapy (yr;mo) \\
\hline A & 36 & M & Undergraduate Degree & Vessel designer & Jeonnam & Moderate (61-70) & None \\
\hline B & 59 & M & High School & Aquaculture industry & Jeonnam & Moderate (51-60) & $0 ; 1$ \\
\hline C & 28 & M & Undergraduate Degree & Officer & Jeonnam & Mild (11-20) & $1 ; 0$ \\
\hline D & 60 & M & Undergraduate Degree & Bank clerk & Gwangju & Severe (81-90) & $0 ; 6$ \\
\hline E & 23 & M & Undergraduate Degree & Military man & Gwangju & Severe (81-90) & $3 ; 0$ \\
\hline $\mathrm{F}$ & 29 & $\mathrm{~F}$ & High School & Housewife & Jeonnam & Mild (21-30) & None \\
\hline G & 35 & M & High School & Transportation business & Gwangju & Moderate (41-50) & $0 ; 1$ \\
\hline $\mathrm{H}$ & 40 & M & Undergraduate Degree & Aquaculture industry & Jeonnam & Moderate (51-60) & $0 ; 5$ \\
\hline | & 35 & $\mathrm{~F}$ & Undergraduate Degree & Civil service & Jeonnam & Mild (31-40) & 2 Weeks \\
\hline J & 42 & M & Undergraduate Degree & Business man & Seoul & Severe (81-90) & None \\
\hline
\end{tabular}

$\mathrm{M}=$ male; $\mathrm{F}=$ female.

는 카페에서 실시하였다. 심층면담에 앞서 참여자에게 연구의 목적 과 의의, 익명성, 연구참여 철회가능성에 대해 설명한 후, 참여동의 서를 받았다. 심층면담은 비구조화된 면담 방식에 따라서 다양한 개념들과 범주들을 찾는 것에 목적을 두고 진행하였다. 비구조화 된 면담 방식은 면담 질문의 내용, 형식, 순서를 면담 상황에 따라서 비교적 자유롭게 자료를 수집하는 방법으로 최소한의 지시나 방 향을 제시하여 참여자로부터 풍부한 실제적인 자료를 얻을 수 있 다. "말더듬성인의 삶의 경험은 어떠한가?”의 연구문제에 대한 실 체이론을 개발하기 위하여 면담 질문은 "말더듬에 대한 경험은 어 떠한가?”라는 포괄적인 질문을 시작으로,"말더듬에 대하여 어떻 게 생각하는가?”, “자신의 말더듬을 어떻게 알게 되었나?”, "말더듬 이 자신의 삶에 어떠한 영향을 주었는가?”, “자신의 말더듬으로 인 해 힘든 점은 무엇인가?”, "말더듬이라는 말을 들으면 심정이 어떠 한가?”, "말더듬 때문에 자신이 하고자 하는 일을 성취하지 못한 것 이 있는가?”, “말더듬성인으로 살아가면서 후회한 적이 있는가?”, "말더듬에 대해서 대처한 방법, 혹은 자신만의 노하우는 무엇인 가?” 등의 좀 더 구체적인 질문을 하였다. 이렇듯 비구조화된 면담 은 연구참여자에게 무엇이 자신에게 중요했었는지에 대해 대답하 도록 유도할 수 있다(Shin, Cho, \& Yang, 2004). 면담을 마친 후 녹 음된 자료는 24 시간 내에 전사하여 컴퓨터에 저장하였으며, 자료수 집과 동시에 분석을 진행하였다. 첫 번째 참여자의 자료로부터 분 석된 결과는 그 다음 참여자의 면담 질문에 반영하여 유사점과 차 이점을 파악하고 비교하면서 면담을 계속하였다. 자료수집 과정에 서 참여자의 반응이나 분석에 도움이 된다고 생각되는 점은 현장 노트에 기록하였으며, 자료분석 과정에서 연구자에게 떠오른 생각 들은 이론적 노트와 전략적 노트에 기록하면서 자료수집을 확대하 였다.

\section{자료분석}

본 연구는 Strauss와 Corbin (1998)이 제시한 근거이론 방법론을 통하여 자료를 분석하였다. 개방부호화를 통해서 드러난 범주들 간의 관계를 연결하는 연결부호화에서는 Strauss와 Corbin (1998) 의 패러다임 모형에 따라 각 범주들을 인과적 조건, 중심현상, 맥락, 중재상황, 전략, 결과로 분류하고 범주들 간의 상호관련성을 시각 적 틀로 제시하였다. 선택부호화에서는 핵심 범주를 중심으로 하 여 맥락적 조건이 되는 각 범주의 속성(properties)과 정도(dimensions)에 따라 상관관계를 정형화하는 가설적 정형화를 수행하였 다. 또한 이를 근거로 유형분석을 세분화하고 시간흐름에 따른 과 정 분석을 실시하였으며 상황적 관계를 파악하여 실체이론을 형성 하였다.

\section{연구의 평가}

본 연구는 Lincoln과 Guba (1985)가 제시한 사실적 가치(truth value), 적용성(applicability), 일관성(consistency), 중립성(neutrality)의 네 가지 기준을 확보하고자 하였다. 사실적 가치는 양적연구 의 내적 타당도에 해당한다. 본 연구에서는 말더듬성인의 풍부하 고 다양한 경험을 추출하기 위하여 말더듬 중증도, 치료 경험의 유 무, 연령, 직업 등을 고려하여 다양한 참여자를 선정하고자 하였다. 적용성이란 양적연구에서는 외적 타당도와 유사한 개념으로 이를 위해서 본 연구에 참여하지 않았던 말더듬성인 1 명과 치료를 종결 한지 3 년이 경과한 말더듬성인 1 인을 대상으로 본 연구결과가 자신 의 경험 과정을 잘 보여주고 있는지를 확인하는 과정을 거쳤다. 일 관성은 양적연구에서의 신뢰도를 의미한다. 이를 위해 본 연구자는 근거이론 방법의 절차를 그대로 따랐다. 제 1 연구자는 박사과정에 서 유창성장애를 전공하였고 질적연구방법에 대한 과목들을 이수 하였으며 두 편의 질적연구를 통하여 실체이론과 유형을 밝힌 바 
있다. 제 1 연구자는 분석 과정과 결과에 대한 객관성을 확보하고자 개념 및 범주를 도출하는 과정에서 수 편의 근거이론 연구 수행과 지도 경험이 20년 이상인 공동연구자 1 과 말더듬치료 경력이 20년 이상인 공동연구자 2 와 수 차례의 논의과정을 통해 일관성을 확보 하고자 하였다. 중립성이란 연구 과정과 결과에서 연구자의 편견이 배제되어야 함을 의미하며 질적연구에서는 앞서 논의된 사실적 가 치, 적합성 및 일관성이 확립될 때 획득된다고 하였다(Lincoln \& Guba, 1985). 연구자는 참여자들과 면담 시 연구자의 주관과 편견 을 배제하기 위하여 비구조화된 면담 방식으로 참여자들의 경험 을 최대한 그대로 반영하고자 노력하였다.

\section{연구결과}

\section{말더듬성인의 삶의 경험의 개념 범주화}

자료를 분석한 결과 모두 251 개의 개념이 도출되었으며, 이 개념 은 <말더듬 발현>, <부담감>, <시선의식>, <비판적 반추>, <굴레>, <지레 겁먹음>, <숨김>, <회피> 등의 33개 하위범주 로 분류되었다. 이들 하위범주는 다시 [놀림감], [두려움], [지레짐 작], [성취욕], [긍정적 추진], [자기 억압], [순응], [체념] 등 16개의 상위범주로 분류되었다. 말더듬성인의 삶의 경험에서 나타난 개념 과 범주를 Appendix 1에 제시하였다.

\section{말더듬성인의 삶의 경험의 패러다임 모형}

Appendix 1 에 제시한 말더듬성인의 삶의 경험에 대한 개념 및 범주에 따라 Strauss와 Corbin (1998)에 근거하여 패러다임 모형을 Figure 1 에 제시하고, 모형에 따라 중심현상, 인과적 조건, 맥락, 작 용/상호작용 전략, 결과에 대하여 아래에 진술하였다.

\section{중심현상(core phenomena):【말더듬의 무의식적 점유: 멍에】}

말더듬성인의 삶의 과정에서 그들이 경험한 것이 무엇인지와 관 련된 일련의 행동은 중심현상인 【말더듬의 무의식적 점유: 멍에】를 중심축으로 펼쳐졌다. 이러한 중심현상은 [말더듬 인지], [놀림감] 이라는 인과적 조건으로 인하여 이들의 내면에서 나타나는 현상으 로서 사회적 맥락 그리고 중재상황과의 상호작용을 거치며 다양한 형태로 변형 또는 발전되거나 해결되는 것으로 나타났다. 시간이 지날수록 말더듬이 심해지게 되는데 말이 막혀서 의사전달이 어렵 거나, 말의 순서를 바꾸는 등 자신도 말의 내용이 헷갈려 소통 장애 를 겪었다. 그러한 경험이 많을수록 자신이 한심하고 멍청해 보여 화가 났으며 자신감이 점점 저하되면서 말더듬을 인생의 걸림돌로 여겼다. 이렇듯 말더듬으로부터 벗어나지 못하는 자신이 밉고 원망 스러우며, 사회적 성공을 이룬 경우라도 만족할 수 없는 이유는 말 더듬이라는 굴레에 갇혀 말더듬이 자신의 삶을 주도했기 때문이 다. 말더듬성인의 삶은 말더듬에 의해 무의식적으로 점유되어 마치

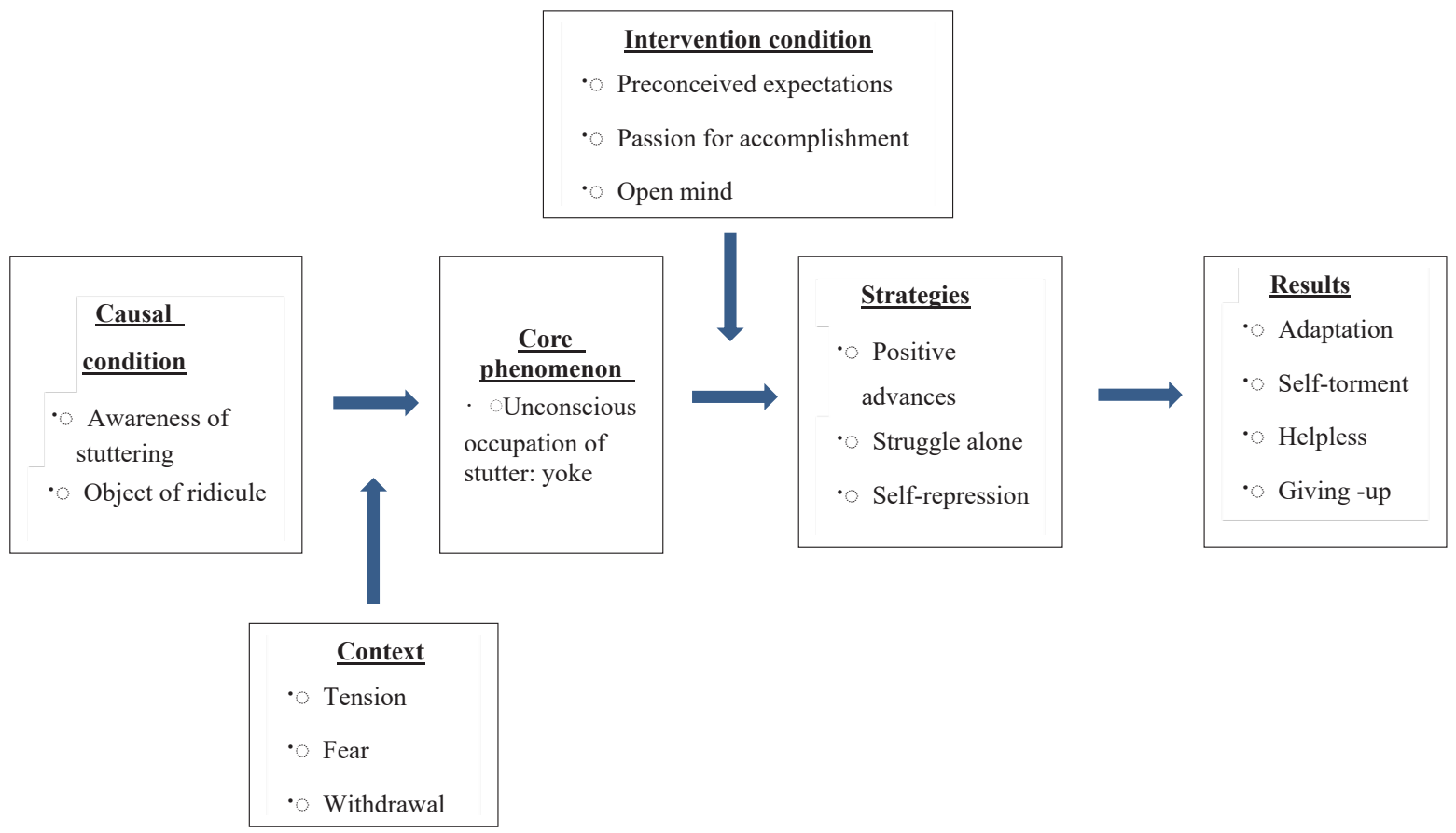

Figure 1. Model of life experiences of adults who stutter. 
소가 ‘멍에’를 매고 있는 모습처럼 그려졌다. 멍에의 사전적 의미는 ‘수레나 쟁기를 끌기 위하여 마소의 목에 얹는 구부러진 막대’이다. 참여자들은 말더듬을 벗어나기 힘들고, 버겁지만 도망칠 수도 없 는 장애물로 여겼는데, 이 모습은 마치 소가 멍에에 매인 모습과 비 슷하였다. 또한 평생토록 말더듬이 완치되지 못하여 누리고자 하 는 삶을 살지 못 할 까봐 두려워하며 말더듬에서 벗어나려는 욕망 이 강하였다. 이는 무의식적으로 말더듬에 삶이 점유당하여 내려 놓지 못하고 스스로 멍에를 지고 있는 모습과 흡사하다. 이에 성인 의 말더듬 경험에 대한 중심현상을 【말더듬의 무의식적 점유: 멍 에】라고 명명하였다.【말더듬의 무의식적 점유: 멍에】의 속성은 정 도이며 정도의 영역은 강함-약함이었다. 분석 자료의 예시를 제시 하면 다음과 같다.

- 네 그러면 말이 안 나와서 순서를 다 바꿔버려요. 그러다가 제 가 무슨 말을 했는지도 헷갈려 버려요. (참여자 C)

$\Rightarrow$ 순서 바꿈, 헷갈림 $\Rightarrow$ <사회적 소통장애 $>\Rightarrow$ [말더듬의 무 의식적 점유:멍에]

- 그래서 내가 토론 같은 것도 이렇게 하고 하면은. 남들은 한 세 번 네 번 하면은 나는 한 번 하고 말고 그런 게 있어요. 하고 싶은 말이 있었는데 아이고 그냥 한번만 하자 하고 말고 그럴 때 너 무 괴롭죠. (참여자 $\mathrm{B}$ )

$\Rightarrow$ 괴로움 $\Rightarrow$ <자신감 저하> $\Rightarrow$ [말더듬의 무의식적 점유: 멍에]

- 모임이나 어딜 갔을 때 별 일 없어야 할 텐데. 실수하거나 뭘 못 하거나 남한테 더듬어가지고 막혀서 말 못했을 때 그런 일 없으 려나 불안한 거. 그러니까 그러다보면 긴장이 되고. 제 삶에 전 부를 빼앗은거죠. 말이. (참여자 $\mathrm{D}$ )

$\Rightarrow$ 내 삶의 전부를 빼앗음 $\Rightarrow$ <걸림돌> $\Rightarrow$ [말더듬의 무의식

적 점유: 멍에]

- 말더듬 아니었으면 더 잘 할 수 있었는데 그런 생각이 아니었을 까요? 저 같은 경우도 제 삶이 사는 게 억울하다는 생각은 많이 하죠. 나도 다른 사람들처럼 말을 안 더듬었으면 좋았을 텐데... (참여자 $\mathrm{H}$ )

$\Rightarrow$ 억울함 $\Rightarrow<$ 한맺힘 $>\Rightarrow$ [말더듬의 무의식적 점유: 멍에]

인과적 조건(causal condition): [말더듬 인지], [놀림감]

성인의 말더듬 경험에 대한 중심현상인 【말더듬의 무의식적 점 유: 멍에 $\boldsymbol{I}$ 를 일으키는 원인, 즉 인과적 조건을 형성하고 있는 것은
[말더듬 인지], [놀림감]으로 파악되었다. 말이 자꾸 끊기거나 막히 고, 대답을 못하는 일이 자주 발생하여 상대방으로부터 말을 더듬 지 말라고 강요를 당하거나, 말을 통제할 수 없어서 자신이 말에 문 제가 있음을 알게되는 [말더듬 인지]와 말을 더듬었을 때 친구들이 나 교사가 말더듬을 따라하거나 웃음거리가 되는 [놀림감]이 중심 현상인 【말더듬의 무의식적 점유: 멍에】에 직접적인 원인으로 작용 한다는 점에서 인과적 조건이라고 할 수 있다. 분석 자료의 예시를 제시하면 다음과 같다.

- 다른 장애 같으면 이해를 해요. 저 사람은 저러니까 하고 이해 를 해주는데... 나는 말을 이렇게 잘 못하고 막히고 끊기고 버벅 거리면서... 그러다가 속사포처럼 터져서 나온다니까요. 전달을 못하니까 미칠 노릇이죠. (참여자 $\mathrm{D}$ )

$\Rightarrow$ 말막힘, 말 끊김, 속사포 $\Rightarrow$ <말더듬 발현> $\Rightarrow$ [말더듬 인지]

- 담임선생님이 심부름을 시켰어요. 그래서 밑에 학년인가 갔는 데 그쪽 선생님이좀 사람이 좀 별로였어요. 제가 답안지를 받으 러 왔다고 그랬더니 제가 더듬으면서 말을 했나 봐요. 그쪽 선생 님이 제 말하는 걸 따라하면서 없다고 그런 식으로 말을 하는 거 에요. 제 기억엔 분명 그 선생님은 말을 더듬는 선생님이 아 닌데 선생님이 하니까 거기 있는 애들이 듣고 막 웃었죠. 그래서 그때도 너무 기분이 나빠서 그 일을 그때 당시 아빠한테 말 했 어요. (참여자 $\mathrm{E}$ )

$$
\Rightarrow \text { 선생님이 따라함 } \Rightarrow<\text { 웃음거리> } \Rightarrow \text { [놀림감] }
$$

\section{맥락(context): [긴장됨], [두려움], [움츠러듬]}

본 연구에서 근거자료를 분석한 결과 【말더듬의 무의식적 점유: 멍에】의 심리적 상황을 만들고 그것을 표출하고 해결하는 모든 전 개과정에 말 막힘에 대한 무서움과 말이 막혔을 때 다른 사람이 대 신 해줘야 하는 [긴장됨]의 정도가 관여됨을 알 수 있었다. 또한 공 식석상에서 말을 실수했던 공포감, 자녀에게 대물림된 말더듬으로 인하여 자식이 받을 지 모르는 고통으로 인한 [두려움]과도 연관이 있었다. 말을 더듬었을 때 상대로부터 질책을 받거나, 무시당하는 경우에 [움츠러듬]이 중심현상인 【말더듬의 무의식적 점유: 멍에】 의 강도에 영향을 미치는 맥락으로 작용하였다. [긴장됨]의 속성은 상태이며, 정도의 영역은 심함-약함이고, [두려움]의 속성은 상태이 며 그 영역은 큼-작음이다. 또한 [움츠러듬]의 속성은 정도이며 그 영역은 강함-약함이다. 분석 자료의 예시를 제시하면 다음과 같다.

- 그때도 마찬가지로 발표할 기회가 되거나 그런 날 있잖아요. 뭐 
3 일이면 13 번 23번 이렇게 되면 친구들한테 말 해놔야 해요. 뒷 번 친구한테 ‘나 오늘 부를 건데 미안한데 책 좀 대신 읽어줘’ 라 고 부탁을 했던 경우가 되게 많았어. 발표하는 수업시간이 너무 부담이 되는 거죠. (참여자 $\mathrm{A}$ )

$\Rightarrow$ 발표부담됨, 다른 사람이 대신 발표 $\Rightarrow<$ 부담감 $>\Rightarrow$ [긴장됨]

- 아침에 일어나면요. 오늘 무슨 일 없으려나 말 때문에? 이를테 면 직장에서 누구 높으신 분이 왔을 때 발표라던지 인사말씀을 제가 해야 할 때가 있으면 아침부터 불안한거죠. 말을 안 끊기고 안 더듬고 차분히 해야 하는데 제 의지하고 관계없이 말이 안돼 요. (참여자 $\mathrm{D}$ )

$\Rightarrow$ 공식석상 말실수 $\Rightarrow$ 말실수 공포증 $>\Rightarrow$ [두려움]

- 그냥 쥐구멍에 들어가고 싶었어요. 그 때 당시에는 발표하고 내 려오는 순간 그 자리에 앉아야하는데 자리에 앉아있는데 주변 사람들의 시선이 느껴지는 거처럼 내 생각이 드는 거에요. 쥐구 멍에 들어가고 싶을 정도로 그 때 되게 기분이 그랬던 거 같아 요. (참여자 $\mathrm{I}$ )

$\Rightarrow$ 피해의식 $\Rightarrow<$ 시선의식 $>\Rightarrow$ [움츠러듬]

\section{중재상황(intervention condition): [지레짐작], [성취욕], [열린 마음]}

중재상황은 주어진 상황에서 전략을 촉진하거나 억제하는 방향 으로 작용하는 범주이다. [말더듬의 무의식적 점유: 멍에I의 생성, 표출, 해결 등 모든 전개과정은 말 막힘이 예상되어 지레 겁을 먹는 [지레짐작]의 정도, 인정받고 싶은 욕구가 강하여 주위로부터 박수 받고 싶은 [성취욕], 말하기 전에 떳떳하게 말더듬을 밝히거나, 반대 로는 가족에게도 자신의 말더듬을 공개하지 못하는 [열린 마음]의 정도가 중재상황으로 드러났다. 참여자들은 이 중재상황에 따라 전략을 선택하여 서로 다른 양상으로 전개되는 것으로 나타났다. [지레짐작]의 속성은 상태이며 정도의 영역은 큼-작음이다. [성취 욕]의 속성은 양상이며 정도의 영역은 강함-약함이고, [열린 마음] 의 속성은 상태이며 정도의 영역은 큼-작음이었다. 분석 자료의 예 시를 제시하면 다음과 같다.

- 아까도 말했듯이 그런 걸 경험을 많이 해보면 될 것 같다는 생 각을 하는데 가장 무서운 건 그런 경험을 처음 했는데 만약에 실수를 했다 그러면 다시 또 안 좋은 기억이 나와 버려요. 그래 서 안 나서려고 하는거죠. 면접을 보면 자꾸 그때가 떠오르니 까... (참여자 $\mathrm{A}$ )

$\Rightarrow$ 안 좋은 기억 떠오름 $\Rightarrow<$ 겁먹음> $\Rightarrow$ [지레짐작]
- 그렇게 잘해서 인정도 받고 싶고, 앞에 나가서 멋지게 발표를 해 서 주변 사람들한테 인정도 받고 싶은데 아 또 나가면 실수할거 같아 말더듬을 거 같아 이런 생각 때문에 아예 내가 차단을 해 버리니까마음에서 상충이 되는 거 같아요. (참여자 I) $\Rightarrow$ 인정받고 싶음 $\Rightarrow<$ 인정 욕구 $>\Rightarrow$ [성취욕]

- 저는 이제 발표할 때는 제가 좀 말을 더듬으니까이해를 좀 해달 라고 사전에 이야기하고 발표한 적도 있었거든요... 학교에서 학 년을 올라가서 반이 바뀌잖아요. 그러면은 이제 뭐 서로 자기소 개를 할 시간이 있다 그러면은 미리 이야기를 했어요. 나는 원 래 말을 더듬으니까 이상하게 생각하지 말고 그런가 보다 하고 생각하라구요. 뭐 감추고 싶다고 해서 감출 수 있는 게 아니니 까요. 그리고 저는 자랑스러운 것도 아니지만 부끄러운 것도 아 니라고 생각하니까요. (참여자 D)

$\Rightarrow$ 떳떳하게 미리 말함 $\Rightarrow<$ 드러냄 $>\Rightarrow$ [열린 마음]

작용/상호작용 전략(action/interaction strategy): [긍정적 추진], [홀로 분투], [자기 억압]

전략이란 현상을 조절하고 반응하려는 참여자의 작용/상호작용 이다. 【말더듬의 무의식적 점유: 멍에I는 그 강도에 따라 서로 다른 양상의 대처 전략을 선택하게 된다. 자료분석 결과 언어치료를 받 거나, 언어치료를 받지 않았지만 복식호흡이나 느리게 말하기 등의 치료기제를 습득해서 사용하는 [긍정적 추진], 말더듬에 대한 잘 못된 정보로 시 낭송이나 판소리를 배우는 등의 자기만의 노하우 를 익히는 [홀로 분투]를 전략으로 사용하였다고 보고하였다. 타인 에게 말더듬 모습을 보이지 않기 위해 상황을 모면하거나, 자포자 기함으로서 승진의 기회를 거절하고 스스로를 억압하여 사회적 성 공의 욕심을 애써 누르는 [자기 억압]을 전략으로 사용하기도 하였 다. 결과적으로 참여자들은 [긍정적 추진], [홀로 분투], [자기억압] 등 서로 다른 대처 전략을 선택하게 됨을 알 수 있다. 분석 자료의 예시를 제시하면 다음과 같다.

- 치료를 받으면서 심리적으로 되게 편해 졌고. 배우기 전보다 많 이 좋아졌죠. 치료 받기 전에는 말더듬는 것을 내가 숨기고 싶 었는데 치료하고 나서는 이게 장애가 아니구나. 떳떳하게 말을 미리 말하고 말 더듬는다고 상대방한테 말하고 그렇게 된 것 같 아요. 긍정적으로 된 것 같아요. (참여자 C) $\Rightarrow$ 언어치료가 도움 됨 $\Rightarrow$ <치료기제사용 $>\Rightarrow$ [긍정적 추진]

- 나는 언어장애 때문에 표현을 못한 것인데 그래도 많은 사람들 
앞에 서보려고 $\cdots$. 자신감이 좀 생기지 않겠나 싶어서요. 근데 그 것이 그 때 뿐이야. 또 다시 또 근본적 치료가 안 되다 보니까. 또 많이 다니는 데가 노인들 경로당을 많이 다녔어요. 왜냐면 말 많이 해보려고 사람 많이 있는데서 애기를 많이 했어요. 제가 양해를 구했어요. 제가 이렇게 그 언어 저 장애가 있어서 이렇 게 연습을 좀 하려고 나왔다고 이해를 해주시라고 그래서 주제 를 가지고 가서... 그러다 보면 애기만 하면 안 될 것 같아서 하모 니카도 한 번씩 불러드리고 판소리도 배운 것도 그 이유죠. (참 여자 D)

$\Rightarrow$ 경로당, 판소리 $\Rightarrow<$ 나홀로 치료 $>\Rightarrow$ [홀로 분투]

- 또 이제 그럴 기회가 또 오게 됐을 때 제가 피하려고 했죠. 윗분 들에게 이야기해서 다른 건 다 하겠는데 남들 앞에서 발표는 도 저히 못하겠다, 이거는 빼 달라 이야기 한 적도 있어요. 사실은. 또 미리 그런 상황에 대해서 걱정이 되니까. (참여자I)

$\Rightarrow$ 발표기회 포기 $\Rightarrow<$ 포기 $>\Rightarrow$ [자기 억압]

\section{결과(consequence): [순응], [통한], [무력감], [체념]}

중심현상이 전략이라는 행동을 통해 해결되는 과정을 근거이론 에서 결과라고 한다. 자료분석 결과 전략을 통해 나타난 결과는 [순응], [통한], [무력감], [체념]으로 도출되었다. [순응]은 말더듬을 긍정적으로 수용하여 평생 함께하는 동반자로 여기며, 여전히 말 을 더듬기는 하지만 말더듬을 편안하게 생각한다. [통한]은 말더듬 을 물려준 부모와 말더듬을 극복하지 못한 자신에 대한 원망, 자책 그리고 후회가 이에 해당된다. 또한 오랫동안 자신만의 방법을 찾 았지만 여전히 고쳐지지 않는 말더듬과 그로 인한 반복되는 굴곡 으로 의욕상실을 경험하며 [무력감]의 결과를 가지게 된다. [체념] 은 아무리 노력해도 고쳐지지 않고, 말더듬에 대안이 없다는 생각 을 하며 말더듬에 둔감해진 결과이다. 분석 자료의 예시를 제시하 면 다음과같다.

- 저는 글쎄... 말더듬은 나의 일부. 나의 뮈... 내 팔이든 다리든 머 리든 내가 말더듬는 한은 그거를 내가 뭐 감춰서 될 문제는 아 니니까 그냥 나의 일부라는 걸 인정을 하고 나랑 지속적으로 볼 사람한테는 그냥 나는 이런 사람이다 라는 걸 알려놓고 그냥 터놓고 맘 편하게 들어가는 쪽을 택했고 (참여자 J)

$\Rightarrow$ 받아들임 $\Rightarrow<$ 자기 인정 $>\Rightarrow$ [순응]

- 그 때 너무 창피하고 부끄럽고 내 자신이 바보 같았죠. 원망스럽 고... 왜 나는 이럴까... 부모님도 원망스럽기까지 해요. 일찍 좀
치료 좀 해주시지... (참여자 $\mathrm{I}$ )

$\Rightarrow$ 원망스러움 $\Rightarrow<$ 후회> $\Rightarrow$ [통한]

- 그럴 때는 미쳐버리겠죠. 사는 것이 무엇이냐. 삶에 대한 의욕이 떨어지는 느낌. 어떨 때는 내가 산에 들어가서 사는 게 좋겠다. 자살까지 충동을 크게 느끼지는 못한 건데... (참여자 $\mathrm{D}$ ) $\Rightarrow$ 삶의 의욕사람짐 $\Rightarrow<$ 의욕상실 $>\Rightarrow$ [무력감]

- 이제는 말더듬으면 그냥 그런가보다 하고... 말더듬으면 그냥 빨 리 다른 말을 해야겠다. 얼른 말을 해야 하는데 갑자기 끊기니 까 또 다른 말을 이어 나가야겠다 그런 생각이에요. (참여자 $\mathrm{F}$ ) $\Rightarrow$ 말더듬에 둔감해짐 $\Rightarrow<$ 대안 없음 $>\Rightarrow$ [체념]

\section{말더듬성인의 삶의 경험 유형분석}

통한형(참여자 $\mathrm{D}, \mathrm{B}, \mathrm{A}, \mathrm{I})$

참여자의 말더듬에 대한 [긴장] 정도가 심하고, [두려움]이 크며 [움츠러듬]이 강하면서, [지레짐작]하여 미리 겁을 먹을 때가 많고 [성취욕]은 강하지만 [열린 마음]을 닫아 숨김이 강하면, [말더듬의 무의식적 점유: 멍에]에 대하여 [홀로분투]와 [자기억압]전략으로 대처하여 [통한]과 [무력감]이 남는다. 이 유형에 해당되는 사례는 참여자 $\mathrm{D}, \mathrm{B}, \mathrm{A}$, 그리고 $\mathrm{I}$ 이다. 참여자 $\mathrm{D}$ 는 말이 통제가 되지 않고 속사포처럼 터져 나와 어릴 적부터 주위의 웃음거리가 되었다. 공 식석상에 서는 것이 가장 공포스럽고, 반벙어리 같은 자신의 모습 때문에 자신감이 상실되었고 자신이 항변할 수 있는 기회를 놓치는 경우에는 한스러움을 경험하였다. 이에 자신을 말더듬이로 낳아준 부모에 대한 원망하는 마음이 컸다. 또한 혼자 있을 때 말더듬으로 인한 수모가 떠오르면 울기도 하고, 억울함으로 소리를 지르기도 하였다. 사회적으로 인정을 받았고 직업적으로도 성공한 삶을 살 았지만, 늘 말더듬이 자신의 삶을 빼앗았다는 패배감에 사로잡혀 있었다. 그래서 자신에게 말더듬은 벗어나고 싶지만 벗어나지 못하 게 하는 족쇄와도 같다고 하였다. 더 높은 지위로 승진을 열망하며 말더듬을 극복하기 위해서 책 읽기, 시 낭송, 판소리 등을 연습하여 경로당을 돌아다니면서 대중 앞에서 더듬지 않고 말하는 연습을 적극적으로 하였으나 오히려 전문기관에 대한 신뢰는 낮았다. 많은 시간을 들여 말 연습을 하였지만 여전히 말더듬에서 벗어날 수가 없어서 말할 기회를 양보하기도 하고, 스스로 승진의 기회를 피하 였던 굴곡이 심한 자신의 처지를 한스럽게 생각하였다.

체념형(참여자 $F, G, H)$

참여자의 말더듬에 대한 [긴장] 정도가 약하고, [두려움]이 크지 
않으나 [움츠러듬]이 강하면서, [지레짐작]하여 미리 겁먹을 때가 많고 [성취욕]이 강하지 않지만 [열린 마음]을 거부하여 숨김이 강 하면, [말더듬의 무의식적 점유: 멍에]에 대하여 [홀로분투]와 [자 기억압]전략으로 대처하여 [체념]이 남는다. 이 유형에 해당하는 참 여자는 $\mathrm{F}, \mathrm{G}$, 그리고 $\mathrm{H}$ 이다. 참여자 $\mathrm{H}$ 는 초등학교 발표시간이나 책 읽기 시간에 말더듬으로 인하여 땀이 날 정도로 긴장되고 힘들었 던 기억이 아직도 생생하다고 하였다. 대학교를 중퇴한 이유도 말더 듬 때문이었고, 직업을 선택할 때에도 되도록 말더듬의 영향을 덜 받는 직업을 선택하여 양식업에 종사하고 있다. 지금도 전화 통화가 힘이 들어 장모의 생신축하 메시지를 핸드폰의 문자메시지로 대신 하고, 주위에 친한 사람이 있을 때에만 전화 통화를 할 수 있다고 한다. 활동적인 성격으로 사람 만나는 것을 좋아하고, 대화 나누는 것을 좋아하므로 이야기를 길게 하다 보면 말더듬이 심해진다고 하 였다. 집에 돌아와서 말을 더듬었던 순간을 되새기면 왜 말을 그렇 게 오래하고 더듬을 때까지 했을까 후회를 하게 되고, 차분히 말하 지 못한 것에 대해 자책감도 있었다. 군대에서도 탈출행동으로 인 하여 오해를 받은 적도 있었다. 말이 막힐 때 주로 다른 말로 바꾸 어 말하거나, 말수를 줄인다고 하였다. 언어치료를 받은 경험이 있 는데 심리적으로는 도움을 받았으나 여전히 말더듬이 심해서 3살 짜리 딸아이에게 동화책을 읽어줄 때도 막힌다고 하였다. 말더듬 을 장애로 생각하고, 자신의 재산의 상당부분을 팔아서라도 말더 듬을 고치고 싶다고 하였으나 말더듬은 완치되기 힘들 것이라고 여 겼다.

\section{순응형(참여자 $\mathrm{C}, \mathrm{E}, \mathrm{J})$}

참여자의 말더듬에 대한 [긴장]정도가 약하고, [두려움]이 크지 않으며 [움츠러듬]이 강하면서, [지레짐작] 정도가 약하고 [성취욕] 이 강하지는 않지만 [열린 마음]을 갖으면, 【말더듬의 무의식적 점 유: 멍에]에 대하여 [긍정적 추진]과 [홀로 분투]전략으로 대처하여 말더듬의 삶에 대해 [순응]하며 살지만 [체념]이 남는다. 이 유형에 해당하는 참여자는 $\mathrm{C}, \mathrm{E}$, 그리고 J이다. 참여자 J는 어린 시절을 떠 올리면 온통 말더듬 기억 뿐이라고 하였다. 특정 음소에서 막힘이 매우 심하고, 투쟁행동이 너무 심하여 이야기를 마치면 몇 미터 앞 까지 진전해 있는 자신을 보게 되었다. 초등학교 때 선생님으로부 터 말더듬 때문에 오해를 받은 적이 있고, 중·고등학생 때는 말더듬 이 너무 심하여 대중교통을 이용하기가 두렵고, 택시를 잡으면 친 구들이 택시 기사에게 행선지를 대신 말해주거나, 물건을 살 때도 친구들이 대신 말을 해주는 일이 자주 있었다. 성인이 되어서도 말 더듬이 직업 선택에 중요한 영향을 미칠 정도이며, 말의 순서를 바 꾸어 말더듬을 모면하기도 하였다. 그러나 참여자 J는 지인들에게
말더듬에 대하여 은폐하지 않았고, 학년이 바뀔 때마다 자신의 말 문제를 공개하였다. 군대에서도 자신의 말더듬을 미리 자기 공개하 여 상사들의 배려와 위로를 받았다. 아버지가 말더듬이 심한 편이 었으나 직업적으로나 사회적으로 성공한 모습을 보고 자랐고, 말 더듬에 대하여 수용적인 가정의 분위기로 말더듬에 대하여 스스럼 없이 식구들에게 털어놓을 수 있었다. 아직도 교회에서 대표기도 가 두렵지만, 말더듬은 자신의 일부라고 생각하고 있으며 예전처럼 말더듬에 전전긍긍하지 않고 편안해졌다.

\section{말더듬성인의 삶의 경험에 대한 과정 분석}

과정의 첫 단계는 말더듬의 ‘발현기’였다. 이 시기에 참여자들은 사람들과의 다름을 느끼게 하는 [말더듬 인지]와 말더듬으로 인하 여 주변으로부터 [놀림감]의 대상이 되었으며, 주로 학령전기나 학 령기인 경우가 많았다. 두 번째 단계는 말더듬의 ‘내재화기'로서, 말 더듬의 발현기에서 겪었던 부정적인 감정과 상황들이 무의식적으 로 떠오르면서 긴장감이 고조되었다. [두려움], [긴장됨], [움츠러 듬]이라는 맥락에 의하여 더욱더 말더듬의 현상이 심화되고 말더 듬의 핵심행동이 드러나든지, 상대방에게 말더듬을 들키지 않기 위해 주로 회피와 도피라는 [자기 억압]의 전략을 선택하게 되는데 이는 말더듬의 부수행동에 해당된다. 이에 말더듬을 들키지 않았 다는 순간적인 안도감은 있지만, 말더듬에 대하여 실패한 자기 모 습에 곧 후회하거나 체념하며 말더듬에 익숙해지는 단계이기도 하 다. 이 시기는 학령기 이후 일생 동안 지속적으로 발생하며, 반복적 으로 순환하는 것이 특징이다. 통한형과 체념형은 이 순환 과정에 서 빠져 나오지 못하고 머물러있다고 할 수 있다. 마지막 단계는 '전 환기'이다. 말더듬에 대하여 어떠한 전략을 사용하느냐에 따라 끊 임없이 반복되는 말더듬의 내재화기에서 벗어날 수도 혹은 벗어나 지 못할 수도 있다. 말더듬에 대한 [열린 마음]을 가지고 [긍정적 추 진]을 하여 말더듬을 적극적으로 수용함으로서 자신의 일부로 받 아들이는 순응하는 삶으로 인식이 전환되는 단계이다. 이 단계까 지 도달한 유형은 순응형의 참여자들이다(Figure 2).

\section{실체이론 형성}

말더듬성인의 삶의 경험에 대한 '말더듬의 무의식적 점유: 멍에 와의 동행'에 대한 이론 모형은 Figure 2에 형상화하였다. 참여자들 은 말더듬의 발현기를 거쳐 내재화기에 들어가게 된다. 참여자들이 의사소통 상황에 직면하게 되면 말더듬으로 인한 부정적인 기억과 감정이 무의식적으로 끊임없이 떠오름으로 긴장이 발생된다. 그 긴 장이 고조되면서 말더듬의 핵심행동과 부수행동을 드러내게 되는 데 핵심행동을 감추기 위해 부수행동인 회피를 선택하게 되면서 


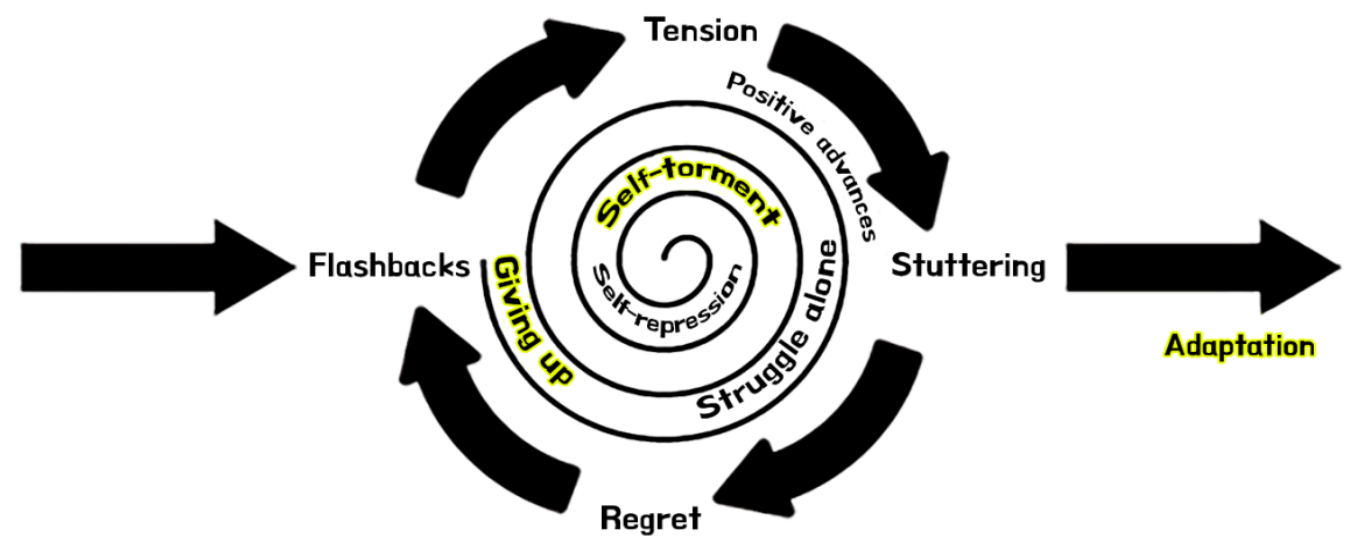

\section{Emergence stages Internalization stages Transitional stages}

Figure 2. Theoretical model of life experiences of adults who stutter.

순간적인 안도감을 갖지만 곧 말더듬을 극복하지 못한 것에 대한 후회를 하게 된다. 그러나 비슷한 상황에 직면했을 때 이전의 부정 적인 감정이 떠오르게 되고 같은 상황으로 들어가는 순환적인 말 더듬의 내재화기에 매여 있게 된다. 긴장이 고조될 때까지는 참여 자들의 유형이 분류되지는 않는다.

참여자들은 말더듬의 내재화기에서 전략을 사용하게 된다. [자 기 억압]의 전략을 사용하는 통한형은 시간이 지날수록 말더듬이 내재화기에서 빠져 나오지 못함에 대하여 [무력감]에 매이게 되어 내재화기의 순환고리에서 가장 안쪽에 자리 잡는 것으로 나타났 다. 다음으로 [홀로 분투]의 전략을 사용하는 체념형의 참여자들 은 말더듬에 둔감해지고 치료에 대한 기대를 접고 살아간다. 이들 은 내재화의 순환고리에서 통한형보다는 조금 더 바깥으로 나와 있는 것으로 나타났다. 말더듬에 대한 [긍정적 추진] 전략을 통하 여 치료기제를 획득한 순응형의 참여자들은 말더듬을 자신의 일 부로 받아들이는 [순응]의 삶으로 전환되어 내재화기에서 빠져 나 오게 된다. 이에 말더듬의 경험이 달라지는 것으로 나타났다.

말더듬성인이 의사소통 시 말더듬에 대한 떠오름의 강도에 따라 긴장의 고조가 좌우되며, 긴장의 정도에 따라 말더듬의 중증도 및 강도가 달라진다. 참여자들이 어떤 전략을 사용하는지에 따라 말 더듬이라는 멍에와 부정적 내지 긍정적 동행 여부에 대한 경험이 다르게 나타난다. 즉, 전략의 선택에 따라 말더듬성인의 삶의 유형 이 달라진다(Figure 2).

\section{논의 및 결론}

본 연구에서 말더듬성인의 삶의 경험에 대한 중심현상은 ‘말더 듬의 무의식적 점유: 멍에'로 분석되었으며, 이에 대한 패러다임과 유형 및 과정을 중심으로 논의 및 임상적 의의에 대해 살펴보고자 한다.

본 연구에서 말더듬성인의 삶의 경험에서 핵심범주는 '말더듬의 무의식적 점유: 멍에와의 동행'으로 나타났다. 말더듬은 주로 학령 전기나 학령기에 발현되며, 성인기에도 지속되는 경우 삶에 여러 가 지로 영향을 미친다. 말더듬의 부정적인 영향으로 인해 말더듬성인 은 학령전기 때부터 말하기 경험을 사회적 처벌로 인식하기도 하며 (Langevin, Packman, \& Onslow, 2009), 말더듬이 만성적인 경우에 이런 경험은 장기간 지속된다(Craig, Blumgart, \& Tran, 2009; Yaruss, 2010). 더욱이 이러한 부정적인 영향은 특히 사회적 불안 및 공포증과 같은 심리적 후유증을 일으킬 수도 있다(Craig, Blumgart, \& Tran, 2011; Messenger, Onslow, Packman, \& Menzies, 2004).

본 연구결과, 말더듬 경험에 대한 인과적 조건은 말더듬 인지와 놀림감으로 분석되었다. 본 연구의 모든 참여자들은 말더듬으로 인하여 친구 놀림이나 선생님의 지적 등을 아주 오랜 기간 동안 경 험하였다. 아동의 말더듬은 괴롭힘(Blood et al., 2011; Langevin, 2015)의 원인이 되고 학교 친구들에 의해 부정적으로 인식되며 주 위에서 놀림감의 대상이 되는데(Langevin et al., 2009) 이는 본 연 
구결과를 지지한다.

또한 참여자들은 다양한 상황에 직면할 때 말을 더듬게 되면서 부정적 감정들이 동반되었다. 말이 막힐 것에 대한 두려움, 사람들 앞에서 더듬으면서 말을 해야 하는 부담감과 긴장감, 말실수에 대 한 공포증 등이 이에 해당되었다. 말더듬의 부정적 감정은 선행연구 들을 통해서도 확인되었다(Bloodstein \& Bernstein Ratner, 2008; Craig \& Tran, 2006; Tran, Blumgart, \& Craig, 2011; Yairi \& Seery, 2011). 말더듬는 시점과 관련된 말더듬 경험에 대한 감정으로는 두 려움, 근심, 불안, 답답함, 공포, 당황, 수치심, 굴욕, 분함 그리고 모 욕감 등이 있다(Yairi \& Seery, 2011). 그 중 말을 더듬는 사람들이 갖는 공통적인 감정은 다양한 상황에서 말하기에 대한 두려움이다 (Yairi \& Seery, 2011). 이러한 긴장감, 두려움과 같은 부정적 감정과 함께 움츠러듬이라는 부정적인 인식도 '말더듬의 무의식적 점유: 멍에’의 맥락으로 작용하였다. 이에 말더듬을 떠올리면 저절로 겁 을 먹게 되는데, 이러한 움츠러듬의 하위범주로는 주변지지, 시선의 식 그리고 성격성향이 해당되었다. Bricker-Katz 등(2013)은 말더듬 성인이 타인으로부터 자신의 역량, 정신 건강 상태 및 지능에 대한 오해를 두려워한다고 하였다. 또한 말더듬성인은 타인으로부터 '모 자라는 사람’으로 인식되거나 평가 받을 것을 고통스러워하며(Sung, 2001), 말더듬으로 인한 부정적인 평가에 대하여 두려워한다(Bricker-Katz, Lincoln \& Mccabe, 2009). 이는 본 연구에서 참여자들이 말더듬 때문에 타인이 자신을 가볍게 보거나, 비웃는 느낌을 들게 하는 부정적 시선의식으로서 본 연구결과와 일치한다. 한편 주변지 지도 맥락으로 작용하였는데, 특히 어릴 적 가정이나 학교에서 가 까운 사람들로부터 말을 더듬는다고 지적 및 질책을 받아 참여자 들로 하여금 말더듬에 대하여 움츠러들게 하였다. 학교 선생님들로 부터 받은 말더듬에 대한 압박으로 인하여 움츠러듬을 확인한 Klompas와 Ross (2004)의 결과가 본 연구를 뒷받침한다. 참여자들 중에 상대적으로 주변지지가 좋은 편인 경우도 있었다. 말더듬에 대해서 수용적인 가정 분위기에서 자랐거나 주변사람들의 도움을 받는 등 성공적인 말더듬 관리 능력 중 첫 번째가 주변지지라고 밝 힌 연구(Plexico et al., 2005)와 일치한다. 또한 참여자들의 성격성 향 때문에 말더듬이 쉽게 고쳐지지 않는 것으로 나타났다. 말더듬 성인들은 자신들의 급한 성격이 행동과 말을 빠르게 하려는 특성 으로 이어지고, 결국 말을 통제하지 못하고 더듬게 된다는 Kim (2015)의 결과가 본 연구를 지지한다. 이와 같이, 말더듬성인의 말 더듬에 대한 부정적인 감정과 인식이 '말더듬의 무의식적 점유: 멍 에'에 대한 맥락적 상황으로 작용하고 있었다.

본 연구에서 참여자들의 말더듬 경험에 대한 중심현상은 '말더 듬의 무의식적 점유: 멍에'였다. 이들은 말더듬으로 인하여 사회적
소통장애와 자신감 저하를 경험하였고 자신의 인생에서 걸림돌이 라고 생각하였다. 이는 Hwang 등(2018)의 결과와도 일치한다. 또한 말더듬에서 벗어나지 못하는 자신을 비판적으로 반추하며 말더듬 을 굴레로 여기며 말더듬에서 벗어나고 싶은 간절한 염원을 가지고 있었다. 이렇듯 말더듬성인들은 일생동안 반복되는 말더듬이라는 멍에의 무게를 버거워하였으며 멍에를 내려놓고 싶어하는 모습을 볼 수 있었다. 그러나 막상 말더듬에 직면하였을 때 이전의 반복된 경험에서부터 온 감정과 인식이 떠오르게 되고 말더듬 행동도 무의 식적으로 되풀이하게 되는 말더듬의 내재화 과정을 순환적으로 경 험하고 있었다.

Langevin 등(2009)은 말을 더듬는 사람들이 주위의 부정적 반 응으로 인하여 자신감 저하, 우울 등과 같은 심리사회적 결과에 장 기간 영향을 받는다고 하였다. 이는 본 연구의 중심현상인 '말더듬 의 무의식적 점유: 멍에’의 하위범주인 자신감 저하에 대한 결과를 지지한다. 또한 자신감 저하를 유발하는 요인으로 불안, 초조, 당황 등이 해당되는데, 특히 말더듬성인의 불안에 대한 연구들을 통하 여 이들이 경험하는 불안의 정도가 얼마나 높은지를 알 수 있다. 말 더듬성인 집단이 정상성인 집단에 비해 사회적 불안이 높게 나타 났다(Kraaimaat, Vanryckeghem, \& Dam-Baggen, 2002). 말더듬 성인이 경험하는 불안은 일반적인 불안 경험 그 이상이며, 말과 관 련된 불안을 넘어서는 수준으로 확대될 수 있다(Iverach et al., 2009). 대인관계에서 말더듬성인이 정상성인보다 사회불안을 더 많이 느 끼며(Kim, 2008), Iverach와 Rapee (2014)도 말더듬성인의 사회불 안 장애가 매우 높은 것을 확인하였다. 이러한 선행연구들의 결과 는 말더듬성인에게 자신감 저하를 유발하는 주요 원인인 불안이 말더듬성인의 평가와 치료 시 반드시 다루어져야 할 요소임을 시사 하고 있다.

말더듬성인은 말더듬에 대한 이전의 부정적인 기억이 떠오르기 때문에 말더듬을 피하게 되고, 말을 더듬는 상황에서 도피하고 싶 은 욕구가 일어난다(Plexico et al., 2009a). Kim (2015)은 말더듬성 인은 주로 청자의 반응에 신경을 많이 쓰는 편으로 이는 오랜 시간 말더듬으로 체험한 기억을 바탕으로 예상하는 것이라고 하였다. 이 는 본 연구에서 말더듬의 경험에 대하여 전략을 선택하는데 관여 하는 중재상황 중 지레짐작과 일맥상통한다. 참여자들은 말을 하 기도 전에 말더듬과 말이 막힐 것이 예견되었고, 이전의 창피했던 기억이 떠오른다고 하였다. 한편 참여자들이 말더듬에 대한 열린 마음이 있는지 없는지도 전략에 영향을 미치고 있었다. 말더듬에 대하여 수용적인 태도를 가진 사람들이 자신의 존재에 대한 긍정 적인 측면을 묘사할 가능성이 더 높고, 말더듬에 대한 긍정적 시각 으로 인하여 자기수용을 촉진할 수 있다(Groomes \& Leahy, 2002) 
는 연구와 유사한 결과로 볼 수 있다. 말더듬성인의 자기 공개는 말 더듬을 인정하는 행동으로서, 타인에게 말더듬에 대한 수용과 이 해를 촉진할 수 있기 때문에 말더듬성인 본인에게 유익할 수 있다 (Lee \& Manning, 2010). 말더듬성인은 청자의 반응에 예민하기 때 문에 긍정적인 청자의 반응을 기대한다면 자기 공개를 가능하게 하는 열린 마음을 갖도록 해야 한다. 또한 자기 공개는 말더듬 중재 시 권장되는 방법으로서 청자들의 부정적인 반응과 말더듬에 대 한 고정관념의 위협을 줄일 수 있다(Byrd et al., 2017; Lee \& Manning, 2010). 청자들은 말더듬에 대하여 자기 공개를 하는 사람을 더 친숙하고, 자신감을 가진 사람으로 평가할 가능성이 높다(Byrd, Croft, Gkalitsiou, \& Hampton, 2017). 본 연구에서 순응형의 참여 자들은 말더듬에 대해 자기 공개를 하였으며, 긍정적인 추진 전략 을 사용하였다. 따라서 언어재활사는 통한형과 체념형의 참여자들 에게 자기 공개에 대한 임상적 유용성에 대한 정보를 제공할 필요 가 있으며, 청자에게서 더 긍정적인 인식과 반응을 유도하기 위해 서는 자기 공개 방식에 대하여도 권유할 필요가 있겠다(Byrd et al., 2017).

참여자들이 말더듬에 대한 회피와 포기라는 '자기 억압’의 전략 을 선택하는 것은 자기 자신이 말더듬에 대한 통제력 상실을 지각 하고 있음을 의미한다. 이는 여러 연구들을 통해서도 입증된 바 있 다(Cooper, 1968; Manning, 2001). 자신이 말더듬을 통제할 수 없 는 스트레스 요인으로 해석한다면, 회피 전략을 선택하는 것이 말 더듬과 같은 만성적인 스트레스 요인에 대한 자연스러운 반응이라 고 할 수 있다. Crichton-Smith (2002), Daniels 등(2006)에서도 말 더듬성인이 사용하는 대처 전략으로 회피가 확인됨으로써 본 연구 와 유사한 결과로 보인다. 말더듬성인의 삶의 경험의 중심현상인 '말더듬의 무의식적 점유: 멍에'의 결과 양상에 따라 말더듬성인의 삶의 유형은 통한형, 체념형, 순응형으로 분류되었다. 통한형은 말 더듬 발현기를 거쳐 말더듬 내재화기에 머물러 있는 상태이다. 이 유형은 말더듬의 멍에를 메고 말더듬의 내재화 과정을 지속적으로 재구성하는 유형으로서, 말더듬에서 도피하고자 자기 억압 전략과 자신만의 방법을 끓임없이 모색하여 홀로 분투 전략을 사용하지만 결국 말더듬을 넘어서지 못함으로써 자신에 대한 통한과 무력감을 느꼈다. 통한형의 참여자들은 말더듬이 삶의 스트레스의 원인으로 서 굴레나 걸림돌로 여겼다. 성취욕구가 강하여 말더듬의 상황을 벗어나기 위해 고군분투하였지만, 전문치료기관에 의뢰하지 않거 나 전문가의 조언을 신뢰하지 못하여 효과적인 치료기제를 획득하 지 못하였다. 이에 매 순간 말더듬에 패배하는 자신에게 실망하며 혼란에 빠지기도 하였다. Plexico 등(2005)에서 말더듬성인이 말더 듬을 성공적으로 관리할 수 없었던 이유로서 청자의 부정적 반응,
본인의 부정적 감정 및 회피로 나타나 본 연구와 같은 의미로 볼 수 있다.

체념형은 통한형과 같이 말더듬의 내재화기에 머물러 있는 상태 이며 전환기로 나아가지 못하였다. 세 유형 중 가장 소극적인 유형 으로, 자신이 처한 말더듬의 멍에를 버겁게 느끼지만, 적극적인 전 략을 취하지는 못하였다. 이들은 적극적으로 말더듬 전문가로부터 치료를 받기보다는 말더듬에 대한 자신만의 노하우를 찾아 다녔 다. Michelle과 Eleanor (2004)도 말더듬성인들이 웅변이나 드라마 에 참여하는 등 자신만의 방법들을 찾는다고 하였다. 또한 본 연구 에서 체념형의 참여자들은 이 마저도 여의치 않으면 자기 억압의 대처 전략도 사용하였다. 오랜 세월을 통하여 말더듬에 대하여 둔 감해지거나, 아무리 노력해도 말더듬은 고쳐지지 않을 것이라 여 겨, 치료에 대한 기대감조차 없으면서 체념하는 결과를 보였다. 말 더듬성인은 오랜 시간 동안 겪은 말더듬에 대한 무력감으로 인하 여 체념을 경험한다(Corcoran \& Stewart, 1998)는 결과는 본 연구 를 지지한다.

순응형은 말더듬의 내재화기에 머물러있지 않고, 말더듬을 자신 의 일부로 받아들여 동행의 대상으로 인식하는 전환 단계로 나아 갔다. 이들은 자신의 말더듬에 대한 내재화 과정에서 긍정적인 추 진 전략을 사용하여 치료기제를 획득하였다. 전문치료기관의 체계 적인 치료를 통하여 말더듬의 중증도가 낮아지거나, 말더듬에 대 한 부정적 감정과 인식이 긍정적으로 전환하는 결과를 보였다. 이 는 성공적으로 말더듬에 대처한 참여자들은 말더듬을 정의적인 특성보다는 자아의 일부로 수용하였고, 말더듬에 의한 스트레스 의 크기를 줄일 수 있었다는 연구(Plexico et al., 2009b)와 유사한 결과이다. 한편 순응형의 참여자들은 다른 유형보다 상대적으로 치료 경험이 많았다. Plexico 등(2009b)의 말더듬에 대한 자기수용 은 나이가 많을수록, 치료 경험이 많을수록 크다고 한 연구결과와 일치한다. 장기적으로 언어치료를 받은 사람들은 치료 프로토콜에 관계없이 다른 사람들보다 더 긍정적인 반응을 보이므로(Huinck \& Peters, 2004) 치료 경험이 말더듬에 대한 자기수용의 가능성에 영향을 미칠 수 있음을 시사한다. 따라서 말더듬의 장기적 치료의 중요성에 대해서 학계 및 임상에서 심도 있는 연구과제로 다루어야 할 필요가 있겠다.

삶에서 만나는 위기에 대한 대처 과정은 스트레스를 주는 상황 에 대한 개인적 평가와 그 사람이 활용할 수 있는 자원 간 상호작용 과정에 따라 적응여부가 결정된다(McCubbin \& Patterson, 1983). 본 연구에서도 말더듬성인이 겪는 어려움은 유형과 과정에 따라 차이가 있었다. 따라서 말더듬이 발현되는 순간부터 말더듬이 내 재화되는 과정 속에서 이들에게 발생하는 두려움이나 긴장과 같은 
감정을 어떻게 처리해야 하는지와 그 상황을 어떻게 대처해야 하는 지를 안내하고 도와줄 실제적인 언어재활사의 역할이 요구된다.

본 연구는 말더듬성인의 삶의 유형과 과정에 근거하여 적절한 언 어치료 프로그램 개발에 기초를 제공하는 실체이론을 구축하였으 므로, 이를 통해 말더듬성인의 언어치료 및 상담 실무를 발전시킬 수 있을 것으로 생각된다. 나아가 말더듬 성인의 삶의 전개를 리뷰 할 수 있었으므로 아동기 상담에도 기초자료로 사용할 수 있을 것 이다. 본 연구결과를 토대로 제한점 및 후속연구를 위한 제언을 하 면 다음과같다.

첫째, 본 연구의 참여자는 주로 말더듬성인 남성으로 편중되었 다. 이에 여성을 대상으로 한 말더듬의 삶의 경험을 근거이론 방법 론으로 분석해 볼 것을 제언한다.

둘째, 본 연구의 참여자는 주로 사설언어치료센터를 통하여 연결 된 대상자들로서 언어치료센터를 찾지 않는 말더듬 성인들이나 성 공적으로 말더듬을 극복한 사례 등을 포함한 다양한 참여자를 대 상으로 삶의 경험에 대하여 분석할 것을 제언한다.

셋째, 말더듬에 대한 부정적 동행을 하는 참여자들의 경험은 말 더듬 자체와 더불어 말더듬에 대한 정보 부족이나 적절한 중재 경 험 부족에 기인할 수도 있으므로 말더듬 아동이나 성인 치료에 대 한 실질적인 교육 및 홍보 프로그램의 개발과 적용이 요구된다.

넷째, 언어재활사의 말더듬 및 말더듬성인에 대한 이해와 좀 더 심층적이며 전문적인 교육프로그램의 개발을 토대로 말더듬성인 의 치료프로토콜의 구축이 활성화되기를 기대한다.

\section{REFERENCES}

Anderson, T. K., \& Felsenfeld, S. (2003). A thematic analysis of late recovery from stuttering. American Journal of Speech-Language Pathology, 12(2), 243-253.

Blood, G. W., Blood, I. M., Tramontana, G. M., Sylvia, A. J., Boyle, M. P., \& Motzko, G. R. (2011). Self-reported experiences of bullying of students who stutter: relations with life satisfaction, life orientation, and self-esteem. Perceptual and Motor Skills, 113(2), 335-364.

Bloodstein, O., \& Bernstein Ratner, N. (2008). A handbook on stuttering (6th ed.). New York: Thomson, Delmar Learning.

Bricker-Katz, G., Lincoln, M., \& Cumming, S. (2013). Stuttering and work life: an interpretative phenomenological analysis. Journal of Fluency Disorders, 38(4), 342-355.

Bricker-Katz, G., Lincoln, M., \& Mccabe, P. (2009). A life-time of stuttering: how emotional reactions to stuttering impact activities and participation in older people. Disability and Rehabilitation, 31(21), 1742-1752.

Byrd, C. T., Croft, R., Gkalitsiou, Z., \& Hampton, E. (2017). Clinical utility of self-disclosure for adults who stutter: apologetic versus informative statements. Journal of Fluency Disorders, 54(1), 1-13.

Choe, K. S. (2005). Grounded theory methodology: Strauss' version vs Glaserian' version. Journal of Korean Academy of Psychiatric and Mental Health Nursing, 14(1), 82-90.

Corcoran, J. A., \& Stewart, M. (1998). Stories of stuttering: a qualitative analysis of interview narratives. Journal of Fluency Disorders, 23(4), 247-264.

Cooper, E. B. (1968). A therapy process for the adult stutterer. Journal of Speech and Hearing Disorders, 33(3), 246-260.

Craig, A., \& Tran, Y. (2006). Chronic and social anxiety in people who stutter. Advances in Psychiatric Treatment, 12, 63-68.

Craig, A., Blumgart, E., \& Tran, Y. (2009). The impact of stuttering on the quality of life in adults who stutter. Journal of Fluency Disorders, 34(2), 6171.

Craig, A., Blumgart, E., \& Tran, Y. (2011). Resilience and stuttering: factors that protect people from the adversity of chronic stuttering. Journal of Speech, Language and Hearing Research, 54(6), 1485-1496.

Crichton-Smith, I. (2002). Communicating in the real world: accounts from people who stammer. Journal of Fluency Disorders, 27(4), 333-352.

Daniels, D. E., Hagstrom, F., \& Gabel, R. M. (2006). A qualitative study of how African American men who stutter attribute meaning to identity and life choices. Journal of Fluency Disorders, 31(3), 200-215.

Groomes, D. A. G., \& Leahy, M. J. (2002). The relationships among the stress appraisal process, coping disposition, and level of acceptance of disability. Rehabilitation Counseling Bulletin, 46(1), 14-23.

Hayhow, R., Cray, A. M., \& Enderby, P. (2002). Stammering and therapy views of people who stammer. Journal of Fluency Disorders, 27(1), 1-17.

Huinck, W. J., \& Peters, H. F. M. (2004). Effect of speech therapy on stuttering: evaluating three therapy programs. IALP Congress: Brisbane.

Hwang, M. J. (2012). A qualitative study on adults with stuttering in 20s-stuttering experiences and perception (Master's thesis). Dankook University, Yongin, Korea.

Hwang, J. E., Hwang, M. J., \& Lee. E. J. (2018). A narrative toward overcoming stutter in adults who stutter. Communication Sciences \& Disorders, 23(3), 740-754.

Iverach, L., O’Brian, S., Jones, M., Block, S., Lincoln, M., Harrison, E., Hewat, S., Menzies, R. G., Packman, A., \& Onslow, M. (2009). Prevalence of anxiety disorders among adults seeking speech therapy for stuttering. Journal 
of Anxiety Disorders, 23(7), 928-934.

Iverach, L., \& Rapee, R. M. (2014). Social anxiety disorder and stuttering: current status and future directions. Journal of Fluency Disorders, 40(2), 69-82.

Kim, M. H. (2015). Adults who stutter perceptions toward stuttering self-disclosure (Master's thesis). Daegu University, Gyeongsan, Korea.

Kim, J. S., Lee, H. G., \& Lee, K. M. (2012). A grounded theory approach to the experiences of middle class drop-outs - focusing on the persons who have tried but failed in reentering the middle class. Korean Journal of Social Welfare Studies, 43(4), 195-230.

Kim, J. Y. (2008). A study on the relationship among stuttering severity, stuttering perception severity and social anxiety of adults who stutter (Master's thesis). Dankook University, Yongin, Korea.

Kim, Y. T., Hong, G. H., Kim, K. H., Jang, H. S., \& Lee, J. Y. (2009). Receptive \& expressive vocabulary test (REVT). Seoul: Seoul Community Rehabilitation Center.

Klompas, M., \& Ross, E. (2004). Life experiences of people who stutter, and the perceived impact of stuttering on quality of life. Journal of Fluency Disorders, 29(4), 275-305.

Kraaimaat, F. K., Vanryckeghem, M., \& Dam-Baggen, R. V. (2002). Stuttering and social anxiety. Journal of Fluency Disorders, 27(4), 319-331.

Langevin, M. (2015). Bullying experienced by youth who stutter: the problem and potential intervention strategies. In K. O. St Louis (Ed.), Stuttering meets stereotype, stigma, and discrimination: an overview of attitude research (pp. 71-90). Morgantown: West Virginia University Press.

Langevin, M., Packman, A., \& Onslow, M. (2009). Peer responses to stuttering in the preschool setting. American Journal of Speech-Language Pathology, 18(3), 264-276.

Lee, K., \& Manning, W. H. (2010). Listener responses according to stuttering self-acknowledgment and modification. Journal of Fluency Disorders, 35(2), 110-122.

Lincoln, Y., \& Guba, E. (1985). Naturalistic inquiry. CA:Sage.

Manning, W. H. (2010). Clinical decision making in fluency disorders (3rd ed.). SanDiego: Singular.

McCubbin, H. I., \& Patterson, J. M. (1983). The family stress, process: the double ABCX model of adjustment and adaptation. In H. I. McCubbin, M. B. Sussman. and J. M. Patterson (Eds.), Social stress and the family (pp. 7-38). New York: The Hayworth Press, Inc.

Messenger, M., Onslow, M., Packman, A., \& Menzies, R. (2004). Social anxiety in stuttering: measuring negative social expectancies. Journal of Fluen- cy Disorders, 29(3), 201-212.

Michelle, K., \& Eleanor, R. (2004). Life experiences of people who stutter, and the perceived impact of stuttering on quality of life. Journal of Fluency Disorders, 29(4), 275-305.

Plexico, L. W., Manning, W. H., \& Levitt, H. (2009a). Coping responses by adults who stutter. Part I. Protecting the self and others. Journal of Fluency Disorders, 34(2), 87-107.

Plexico, L. W., Manning, W. H., \& Levitt, H. (2009b). Coping responses by adults who stutter. Part II. Approaching the problem and achieving agency. Journal of Fluency Disorders, 34(2), 108-126.

Plexico, L. W., Manning, W. H., \& DiLollo, A. (2005). A phenomenological understanding of successful stuttering management. Journal of Fluency Disorders, 30(1), 1-22.

Shin, K. L., Cho, M. O., \& Yang, J. H. (2004). Qualitative research methodology. Seoul: Ewha Woman University.

Sim, H. S., Shin, M. J., \& Lee, E. J. (2010). Paradise-Fluency assessment II. Seoul: Paradise Welfare Foundation.

Smith, A. (1999). Stuttering: a unified approach to a multifactorial, dynamic disorder. In N. Bernstein Ratner \& E. Charles Healey (Eds.), Stuttering research and practice: Bridging the gap (pp. 27-44). Mahwah, NJ: Lawrence Erlbaum Associates.

Stern, P. N. (1980). Grounded theory methodology: its uses and processes. Image, 12(1), 20-23.

Stewart, T., \& Richardson, G. (2004). A qualitative study of therapeutic effect from a user's perspective. Journal of Fluency Disorders, 29(2), 95-108.

Strauss, A., \& Corbin, J. (1998). Basics of qualitative research: techniques and procedures for developing grounded theory (2nd ed.). Thousand Oaks, CA: Sage.

Sung, J. A. (2001). The factors influencing listeners' perceptions of adult stutterers (Master's thesis). Yonsei University, Seoul, Korea.

Tetnowski, J. A., \& Damico, J. S. (2001). A demonstration of the advantages of qualitative methodologies in stuttering research. Journal of Fluency Disorders, 26(1), 17-42.

Tran, Y., Blumgart, E., \& Craig, A. (2011). Subjective distress associated with chronic stuttering. Journal of Fluency Disorders, 36(1), 17-26.

Van Riper, C. (1982). The nature of stuttering (2nd ed.). Englewood Cliffs, NJ: Prentice-Hall.

Yairi, E., \& Seery, C. H. (2011). Stuttering foundations and clinical application (2nd ed.). Boston: Pearson.

Yaruss, J. S. (2010). Assessing quality of life in stuttering treatment outcomes 
research. Journal of Fluency Disorders, 35(3), 190-202.

Yaruss, J. S., \& Quesal, R. W. (2004). Stuttering and the international classification of functioning, disability, and health (ICF): an update. Journal of Communication Disorders, 37(1), 35-52.
Yaruss, J. S., Quesal, R. W., \& Murphy, B. (2002). National Stuttering Association members' opinions about stuttering treatment. Journal of Fluency Disorders, 27(3), 227-242. 


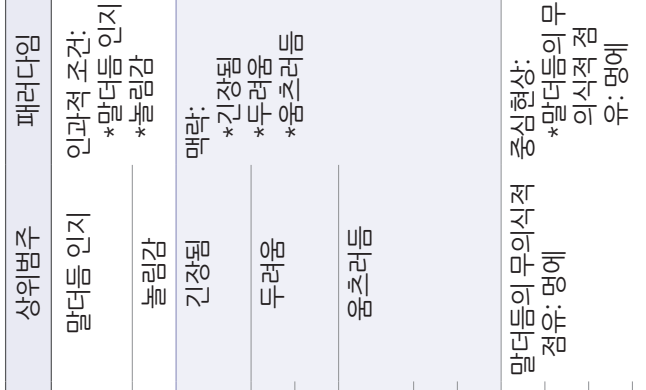

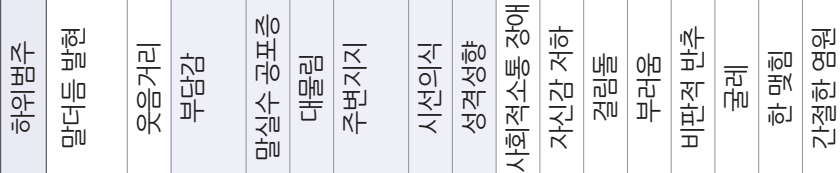

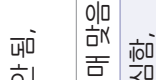

이미밀

犃 吾

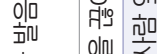

市」

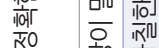

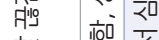

和 舵

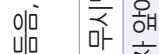

岀 010 夜

吅 0 KK

腙 五

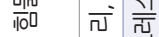

市

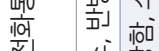

市」 留

엄 ज玟

के 사 알

就所 勍 마

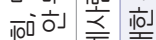

犃题 雼

파 내0 내0 $\bar{O}$

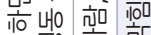

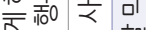

तٓ

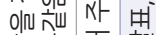

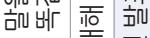

번헣 총

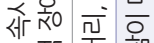

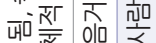

사

ठ」 $\frac{2}{\gtrless}$ OK

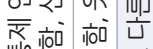

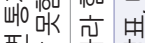

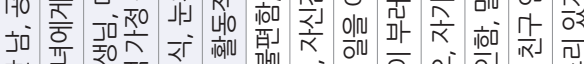

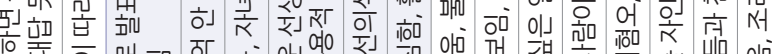

임

임

엉

(in

$\frac{\mathrm{U} \mid \mathrm{O}}{\mathrm{U}}$

犃

뜸

京

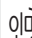

핲

네에

마

夜

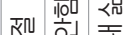

ড๋」

状

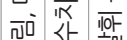

就

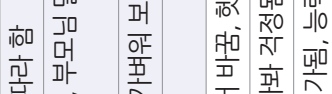

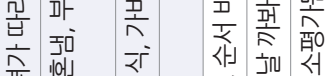

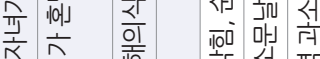

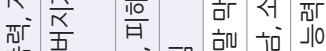

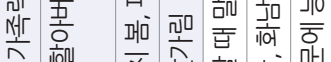

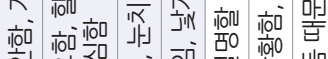

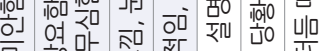

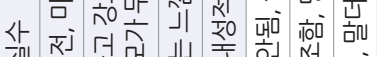

राप

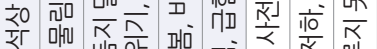

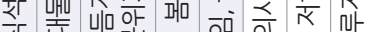

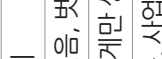

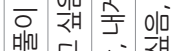

마 메 덛 少

क्व

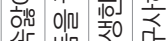
सए 顸部

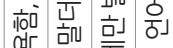
예

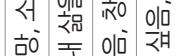

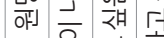

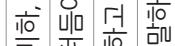

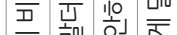

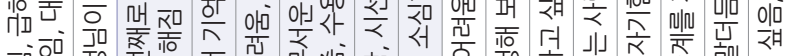

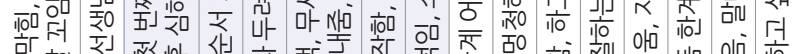

가 竞罂

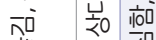

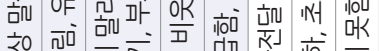

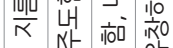
겅 이 야

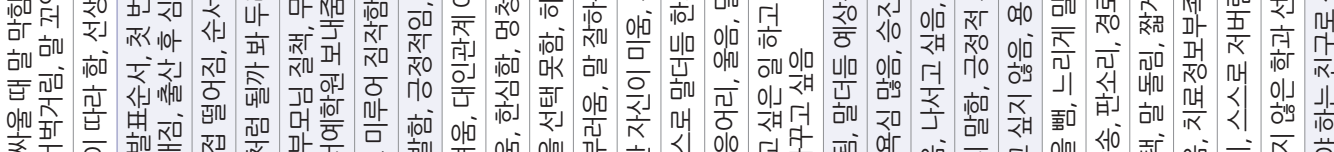

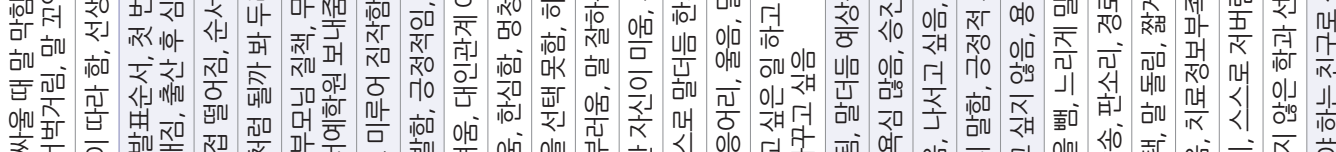

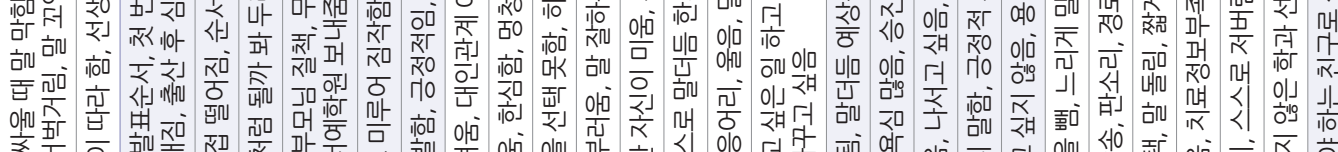

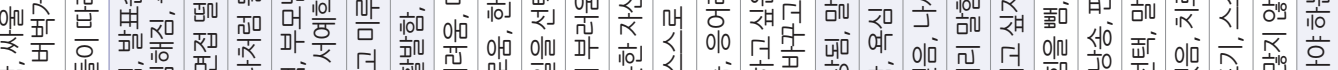

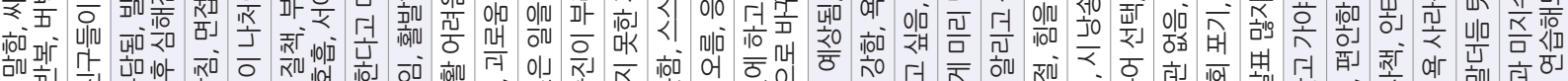

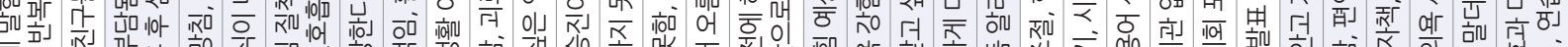

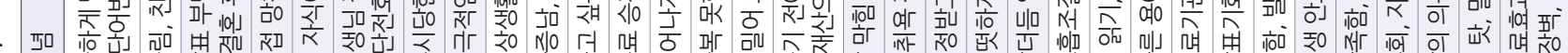

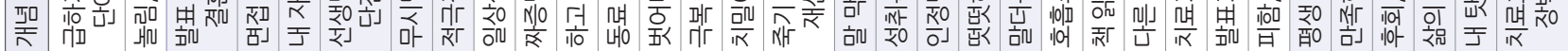




\section{국문초록}

\section{말더듬성인의 삶의 경험의 근거이론적 분석}

최소영 1 송미승 2 신문자 ${ }^{3}$

1목포언어청각센터, ${ }^{2}$ 세한대학교 간호학과, ${ }^{3}$ 조선대학교 언어치료학과

배경 및 목적: 본 연구는 말더듬성인의 삶의 경험을 규명하여 근거이론으로 정립함으로써, 언어재활사들이 임상현장과 지역사회에서 말더듬성인의 중재를 하는데 기여할 이론적 틀을 제시하기 위하여 시도되었다. 방법: Strauss와 Corbin (1998)이 제시한 근거이론 연구 방법을 적용하여 총 10 명의 말더듬성인을 대상으로 심층면담을 통하여 자료를 수집하고 분석하였다. 결과: 본 연구를 통해 말더듬성인 의 삶의 경험에 대한 중심현상은 【말더듬의 무의식적 점유: 멍에I로 나타났다. 말더듬성인은 [긴장됨], [두려움], [움츠러듬]이라는 맥락 과 [지레짐작], [성취욕], [열린 마음]의 중재상황 속에서 [긍정적 추진], [홀로 분투], [자기 억압]이라는 전략을 사용하였고, 결과는 [순 응], [통한], [무력감], [체념]으로 나타났다. 말더듬성인의 삶의 경험은 '통한형, '체념형', '순응형'으로 분류되었으며, '발현기, '내재화기', '전환기'로 과정이 분석되었다. 논의 및 결론: 말더듬성인의 삶은 '말더듬의 무의식적 점유: 멍에와의 동행'으로 나타났으며 이에 대한 관련요인을 분석하였다. 말더듬성인 치료 시 말더듬 경험에 대한 유형과 과정에 따라 실제적으로 적용 가능한 중재 및 상담 프로그램의 개발과 적용이 요구됨을 논의하였다.

핵심어: 말더듬성인, 삶의 경험, 근거이론

이 논문은 제1저자(최소영)의 박사학위논문의 일부를 발췌한 것임.

\section{참고문헌}

김민혜 (2015). 말더듬 자기 공개에 대한 말더듬성인의 인식. 대구대학교 대학원 석사학위논문.

김영태, 홍경훈, 김경희, 장혜성, 이주연 (2009). 수용·표현어휘력검사(REVT). 서울: 서울장애인종합복지관.

김진숙, 이혁구, 이근무 (2012). 중산층에서 탈락한 개인들의 경험과정에 대한 근거이론접근: 재진입 시도와 실패를 경험한 자를 중심으로. 사회복지

연구, 43(4), 195-230.

김주연 (2008). 말더듬성인의 말더듬 정도 말더듬 지각 정도 사회불안 간의 관계. 단국대학교 대학원 석사학위논문.

성진아 (2001). 말더듬성인에 대한 듣는 사람의 인식에 영향을 주는 요인들. 연세대학교 대학원 석사학위논문.

신경림, 조명옥, 양진향 (2004). 질적연구방법론. 서울: 이화여자대학교 출판부.

심현섭, 신문자, 이은주 (2010). 파라다이스-유창성검사 II. 서울: 파라다이스 복지재단.

황민지 (2012). 20대 말더듬성인의 말더듬 경험에 대한 질적연구. 단국대학교 대학원 석사학위논문.

황지은, 황민지, 이은주 (2018). 말더듬성인의 말더듬 극복을 향한 내러티브. Communication Sciences \& Disorders, 23(3), 740-754.

최귀순 (2005). Strauss와 Glaser의 근거이론방법론 비교. 정신간호학회지, 14(1), 82-90.

\section{ORCID}

최소영(제1저자, 언어재활사 https://orcid.org/0000-0001-8115-2935); 송미승(교신저자, 교수 https://orcid.org/0000-0002-9540-8046);

신문자(공동저자, 교수 https://orcid.org/0000-0003-3279-7221) 